\title{
PERAN PENDIDIKAN KEWIRAUSAHAAN DAN MOTIVASI BERWIRAUSAHA DALAM MENUMBUHKAN SIKAP MENTAL KEWIRAUSAHAAN PESERTA DIDIK
}

\author{
Ani Interdiana Candra Sari ${ }^{1(*)}$, Elin Karlina ${ }^{2}$, Fadli Rasam ${ }^{3}$ \\ Universitas Indraprasta PGRI, Indonesia ${ }^{123}$ \\ incasani26@gmail.com ${ }^{1}$, elinkarlina27@yahoo.com², fadrasam@gmail.com ${ }^{3}$
}

\section{Received: 28 Juli 2021 \\ Revised: 22 Agustus 2021 \\ Accepted: 02 September 2021}

\begin{abstract}
Riset ini bertujuan untuk memperoleh jawaban secara empirik pengaruh (1) pendidikan kewirausahaan dan motivasi berwirausaha terhadap sikap mental berwirausaha peserta didik secara simultan, (2) pendidikan kewirusahaan terhadap sikap mental berwirausaha peserta didik secara partial, (3) motivasi berwirausaha terhadap sikap mental berwirausaha peserta didik secara partial. Penelitian ini dilaksanakan di SMA N 21 Bekasi dengan responden 104 peserta didik. Penelitian ini menggunakan Metode survei dengan pendekatan analisis regresi linear ganda. Berdasarkan penelitian dan perhitungan SPSS diperoleh hasil penelitian sebagai berikut: (1) Terdapat pengaruh pendidikan kewirausahaaan dan motivasi berwirausaha terhadap sikap mental berwirausaha peserta didik secara simultan. (2) Terdapat pengaruh pendidikan kewirausahaan terhadap sikap mental berwirausaha peserta didik secara partial (hal ini menandakan bahwa pendidikan kewirausahaan yang diberikan sekolah terbukti dapat meningkatkan sikap mental berwirausaha). (3) Terdapat pengaruh motivasi berwirausaha terhadap sikap mental berwirausaha secara partial (hal ini menandakan bahwa motivasi berwirausaha yang diberikan guru pada saat proses belajar dan pembelajaran tebukti dapat meningkatkan sikap mental). Pendidikan kewirausahaan yang ada di sekolah dan dengan pemberian motivasi berwirausaha pada saat proses pembelajaran dapat mempengaruhi sikap mental peserta didik dalam berwirausaha
\end{abstract}

Keywords: Pendidikan Kewirausahaan, Motivasi Berwirausaha, Sikap Mental Berwirausaha

(*) Corresponding Author: Sari, incasani26@gmail.com

How to Cite: Sari, A. I. C., Karlina, E., \& Rasam, F. (2021). Peran Pendidikan Kewirausahaan Dan Motivasi Berwirausaha Dalam Menumbuhkan Sikap Mental Kewirausahaan Peserta Didik. Research and Development Journal of Education, 7 (2), 403-412.

\section{INTRODUCTION}

Banyaknya penduduk yang tidak bekerja dan sulitnya untuk memenuhi segala kebutuhan hidup masih menjadi permasalahan di Indonesia. Pengangguran dan kemiskinan terjadi karena tidak seimbangnya lapangan pekerjaan dengan jumlah lulusan dalam segala tingkat Pendidikan (Saiman, 2014). Indonesia jumlah pengangguran terbanyak justru dari kelompok terdidik.

Tabel 1.

Pengangguran Terbuka Nasional Menurut Pendidikan Tertinggi yang Ditamatkan 2015 - 2018

\begin{tabular}{llcccc}
\hline No & $\begin{array}{c}\text { Pendidikan Tertinggi yang } \\
\text { ditamatkan }\end{array}$ & $\mathbf{2 0 1 5}$ & $\mathbf{2 0 1 6}$ & $\mathbf{2 0 1 7}$ & $\mathbf{2 0 1 8}$ \\
\hline 1 & Tidak/belum pernah sekolah & 179857 & 153639 & 155315 & 42039 \\
2 & Tidak/belum tamat SD & 974736 & 941487 & 951332 & 446812 \\
\hline
\end{tabular}




\begin{tabular}{llcccc}
\hline 3 & SD & 2325353 & 2254685 & 2196795 & 967630 \\
4 & SLTP & 3024306 & 2608298 & 2555657 & 1249761 \\
5 & SLTA umum/SMU & 4042440 & 3497325 & 3463723 & 1650636 \\
6 & SLTA Kejuruan/SMK & 2744056 & 2868876 & 3004424 & 1424428 \\
7 & Akademi/Diploma & 505853 & 469098 & 492642 & 300845 \\
8 & Universitas & 1218988 & 1262539 & 1225697 & 789113 \\
\hline 9 & Total & $\mathbf{1 5 0 1 5 5 8 9}$ & $\mathbf{1 4 0 5 5 9 4 7}$ & $\mathbf{1 4 0 4 5 ~ 5 8 5}$ & $\mathbf{6 8 7 1 2 6 4}$ \\
\hline \multicolumn{2}{l}{ Sumber } & Survei Angkatan Kerja Nasional (www.bps.go.id), (2018)
\end{tabular}

Banyaknya pegangguran disebabkan karena ledakan jumlah penduduk yang terus meningkat tanpa diimbangi dengan lapangan pekerjaan yang memadai dan minimnya niat untuk menciptakan lapangan pekerjaan. Sebenarnya, dengan berwirausaha atau berminat menciptakan lapangan kerja memberikan dampak yang baik untuk diri sendiri dan lingkungan sekitar.

Masalah dalam dunia pendidikan mendapatkan perhatian yang sungguh-sungguh dari pemerintah. Pemerintah berupaya untuk meningkatkan mutu pendidikan, melakukan pembangunan dan pembaharuan di bidang pendidikan. Pembangunan tersebut meliputi pembangunan berbagai sarana fisik dan non fisik yang menunjang kelancaran pendidikan dan penyempurnaan dan peraturan-peraturan tentang pendidikan yang sesuai dengan undang-undang serta pembaharuan dalam proses belajar mengajar, meningkatkan kualitas tenaga pendidikan antara lain guru. Pemerintah telah mengeluarkan Instruksi Presiden Nomor 4 Tahun 1995 tentang Gerakan Nasional Memasyarakatkan dan Membudayakan Kewirausahaan. Amanat tersebut berisi diharapakan untuk seluruh rakyat Indonesia mampu memciptakan lapangan pekerjaan atau mampu menjadi wirausahawan. Kewirausahaan yaitu keterampilan yang mampu menghasilkan suatu usaha. Kemampuan menciptakan dan memerlukan gagasan yang unik dan mampu mengembangkan sesuatu yang berbeda dengan cara ATM (amati, tiru, dan mpdifikasi). Keahlian dalam menciptakan usaha baru yang unik, berbeda, gigih, tangguh, siap bersaing, dan mampu membaca peluang akan melahirkan wirausahawan yang sukses (Suryana, 2013).

Menurut (Sugihartono dkk, 2013), pendidikan adalah suatu daya upaya secara sadar dalam mengubah ranah pengetahuan, sikap, dan keterampilan baik secara perorangan dan kelompok menuju kedewasaan melalui proses pembelajaran sehingga melahirkan generasi yang memiliki rasa tanggung jawab atas segala yang dilakukannya. Guru merupakan orang tua kedua disekolah yang bertugas mendidik, mengajar, membimbing, melatih, menilai, mengevaluasi, pemimpin yang mampu menciptakan suasana pembelajaran yang menarik, inovatif, kreatif, aman, kondusif, selama berlangsungnya proses pembelajaran. Lingkungan belajar yang kondusif dan menarik mampu menciptakan suasana pembelajaran menjadi bergairah dan mampu mencapai tujuan pembelajaran yang telah dirumuskan.

Kewirausahaan atau entrepreneurship merupakan budaya tak berwujud yang dapat menciptakan budaya yang berwujud (Sumarsono, 2010). Menurut Schumpeter dalam (Sumarsono, 2010) mengatakan bahwa wirausahawan adalah pembaharu. Artinya hanya seseorang yang dapat melakukan perubahan yang dapat disebut inovator. Wirausahawan adalah seseorang yang mampu menghasilkan usaha yang unik, berbeda, mencari peluang baru dengan berbagai resiko dalam ketidak tentuan kondisi untuk menhasilkan pendapatan dan perkembangan dengan berbagai strategi dalam menciptakan peluang bisnis dengan menyatukan berbagai sumber daya untuk menghasilkan sumber daya yang maksimal (Zimmerer, 2008).

Sesuai dengan amanah dari Instruksi Presiden Nomor 4 Tahun 1995 tentang Gerakan Nasional Memasyarakatkan dan Membudayakan Kewirausahaan. Pemerintah menyadari bahawa dunia usaha atau bisnis merupakan tumpuan bagi perekonomian nasional, sehingga harus ditingkatkan secara terus menerus. Diharapkan dengan adanya 
Gerakan membudayakan kewirausahaan menjadi bagian dalam tujuan pembelajaran disekolah dan mampu menarik peserta didik untuk menciptakan lapangan pekerjaan daripada mencari pekerjaan, sehingga diharapakan mampu melahirkan generasi Indonesia yang memiliki jiwa wirausahawan yang kreatif, inovatif, menciptakan peluang, handal, mandiri, dan bertanggung jawab. Pendidikan kewirausahaan bertujuan untuk membentuk manusia secara utuh, sebagai insan yang memiliki karakter, pemahaman dan keterampilan sebagai wirausaha.

Sikap mental kewirausahaan pada peserta didik akan ditanamkan melalui pendidikan kewirausahaan sesuai nilai-nilai kewirausahaan (Suryana, 2013). Kemendiknas dalam (Mulyani, 2012), mengintegrasikan nilai-nilai kewirausahaan melalui pendidikan kewirausahaan sebagai berikut: Jujur, Disiplin, Kerja Keras, produktif dan imajinatif, Pembaharuan, Independen, Tanggung-jawab, Kooperatif, Kepemimpinan, ulet, Berani Menanggung Resiko, Komitmen, Realistis, Rasa ingin tahu, Komunikatif, Motivasi kuat untuk sukses, Berorientasi pada tindakan. Berdasarkan nilai-nilai di atas peneliti mengambil 5 nilai yang dijadikan sebagai indikator yaitu: Inovatif, Realistis, Kreatif, Komunikatif, dan Mandiri.

Siswa Sekolah Menengah Atas (SMA) perlu memiliki sikap mental kewirausahaan tinggi karena dalam kurikulum mereka ada mata pelajaran Prakarya dan Kewirausahaan (PKWU) yang dapat membentuk sikap mental kewirausahaan. Seharusnya itu menjadi motivasi agar setelah lulus dari SMA dapat berwirausaha. Peserta didik yang sudah dibekali dengan pendidikan kewirausahaan diharapkan mampu mengaplikasikan ilmu tersebut setelah lulus dari SMA. Pendidikan kewirausahaan dapat membentuk keterampilan kognitif, afektif, dan psikomotorik peserta didik menjadi seorang wirausahawan (entrepreneur) sejati sehingga mengarahkan mereka untuk memilih berwirausaha sebagai pilihan karir. Alasan peneliti memilih SMA Negeri 21 Bekasi, karena sekolah tersebut baru akan meluluskan peserta didik pada tahun ajaran 2018/2019. Diharapkan setelah lulus nanti peserta didik bisa menentukan pilihan apakah akan melanjutkan kejenjang perguruan tinggi atau berwirausaha agar tidak banyak menimbulkan pengangguran. Melalui pendidikan kewirausahaan dan motivasi yang sudah diberikan, setidaknya peserta didik sudah mempunyai sikap mental dalam berwirausaha.

Sikap mental kewirausahaan merupakan sikap atau pondasi awal yang dimiliki oleh pelaku bisnis. Sikap ini dapat ditanamkan melalui Pendidikan kewirausahaan disekolah, pendidik mampu membentuk sikap mental kewirausahaan dalam diri siswa dengan menanamkan nilai-nilai kewirausahaan. Selain itu sikap mental kewirausahaan dapat dibentuk karena adanya motivasi. Motivasi atau dorongan untuk berwirausaha dalam diri peserta didik salah satunya adalah agar menjadi kebanggaan orang tua. Peserta didik di tingkat SMA memang bukan untuk disiapkan bekerja, namun alangkah baiknya jika peserta didik yang dibekali pendidikan kewirausahaan ini bisa menciptakan lapangan kerja, karena berwirausaha adalah peluang menuju sukses dengan usaha sendiri. Dengan bekal ilmu dan praktik yang diperoleh sejak SMA diharapkan peserta didik memiliki motivasi dan sikap mental dalam berwirausaha.

Sikap menurut (Slameto, 2010) adalah segala yang ditelaah serta bagaimana setiap orang memberikan tanggapan terhadap rangsangan yang didapatkan serta mampu menuntut tercapainya tujuan dalam hidup. Secara umum, pengertian sikap (attitude) merupakan apa yang diamanati, dirasakan, dipikirkan terhadap sesuatu yang didapat dari lingkungan. Dengan memahami atau mengetahui sikap individu, dapat diperkirakan respons ataupun perilaku yang akan diambil oleh individu yang bersangkutan. Secara umum, terdapat tiga ranah perilaku yang dimiliki seseorang, yaitu: Kognitif, Afektif, dan Psikomotorik.

Sebagai pelaku wirausaha, harus mempunyai sikap mental yang berani mengambil berbagai resiko dengan berbagai pertimbangan yang baik mampu menciptakan 
keberhasilan. Charles Schriciber dalam (Alma, 2014) menyatakan bahwa keberhasilan individu dipengaruhi oleh pengetahuan sebesar $15 \%$ dan karakter $85 \%$.

Sikap kewirausahaan di pengaruhi oleh: (Suryana, 2013):

1. Faktor individu: Pengendalian diri, penerimaan dalam segala hal, pengambilan resiko, kepribadian, pendidikan, pengalaman, umur, komitmen dan rasa tidak puas.

2. Faktor lingkungan: kesempatan, model peran, kegiatan, kompetitor, inkubator, sumber daya dan kebijakan pemerintah.

3. Faktor lingkungan sosial: keluarga, orang tua dan kelompok.

Sikap mental kewirausahaan merupakan perilaku individu yang mempunyai rasa tanggung jawab, mengikuti perkembangan zaman, pantang menyerah, serta tangguh. Pelaku wirausaha diharapkan mempunyai sikap mental siap dikritik dan menerima saran dari berbagai pihak serta mampu melaksanakannya untuk mencapai tujuan dan keberhasilan usaha.

Menciptakan perilaku merupakan proses menghasilkan kultur atau kedewasaan individu dalam membentuk karakter yang berbeda, istimewa, mengagumkan, dan memiliki ciri khas terendiri sehingga mudah dibedakan dengan yang lain. Begitu berartinya karakater dalam kewirausahaan adalah perilaku sebagai tumpuan bagi kecerdasan dan pengetahuan pelaku wirausaha. Sikap adalah organisasi yang relatif kekal dari sebuah kepercayaan, rasa, perilaku sebagai makhluk sosial secara objek, komunitas, kejadian, dan lambang. Perilaku didukung oleh tiga komponen, yaitu: komponen pengetahuan merupakan penyampaian kembali yang didapatkan seseorang. Komponen sikap merupakan rasa yang berkaitan dengan aspek emosional. Komponen konatif merupakan aspek kecenderungan berperilaku tertentu sesuai dengan sikap yang dimiliki oleh seseorang (Maulida et al., 2016).

Terdapat enam kekuatan untuk membangun kepribadian yang kuat, yaitu: Kemauan yang keras, Keyakinan kuat atas kekuatan sendiri, Kejujuran dan tanggung Jawab, Ketahanan fisik dan mental, Ketekunan dan keuletan untuk bekerja keras, dan Pemikiran yang konstruktif dan kreatif (Sunarso, 2010). Wirausaha sukses dengan N Ach (Need for Achievement) kebutuhan untuk berprestasi tinggi mampu menganalisis diri sendiri dengan berbagai kelebihan dan kekurangan. $N$ Ach merupakan lambang utama dari motivasi kewirausahaan. Motivasi berwirausaha timbul karena kemauan untuk berprestasi. Semakin mempercayai dirinya memiliki prestasi, maka prestasi akan mewujudkan prestasi yang lebih baik dan tinggi (Sumarsono, 2010). Dorongan untuk berwirausaha harus memiliki semangat untuk berhasil, mau belajar dari keberhasilan orang lain, mempunyai motivasi untuk menjawab setiap tantangan dalam berwirausaha. Di lingkungan sekolah, pendidik mampu memotivasi peserta didik untuk menjadi wirausahawan dengan cara mengkaitkan mata pelajaran teori dengan praktek berwirausaha. Motivasi bagi peserta didik diharapkan setelah lulus sekolah mampu menciptakan lapangan kerja baru atau menjadi wirausahawan daripada bekerja dengan orang lain, karena sekecil apapun usaha yang dimiliki saya adalah bosnya. Dengan berwirausaha banyak manfaat yang didapatkan, yaitu: mampu membatu orang lain untuk mendapatkan penghasilan, membatu pemerintah dalam mengatasi pengangguran, dapat meningkatkan taraf hidup bagi pelaku bisnis, mampu menghidupkan bisnis dengan berbagai bisnis.

McClelland dalam (Sumarsono, 2010) mengemukakan bahwa secara psikologis yang menjadi motor penggerak utama bagi wiraswastawan adalah motivasi untuk berprestasi, yang ditandai sebagai $N$ Ach merupakan kebutuhan yang mampu memotivasi seseorang mencapai tujuan yang diinginkan. David Mc Clelland dalam (Sumarsono, 2010) menemukan adanya hubungan antara perilaku seseorang yang mempunyai motivasi prestasi tinggi dengan tingkah laku wirausaha. karakter wirausaha yang dicerminkan 
dalam sikap dan dorongan terhadap karir dan prestasi yang berhasil, akan dicerminkan dalam tindakan-tindakan sebagai berikut: (Sumarsono, 2010)

1. Meniru seseorang yang sukses dalam bidang pekerjaan dan mengidentifikasi strategistrategi untuk mencapai sukses

2. Memanfaatkan inovasi untuk memotivasi diri

3. Berorientasi pada tindakan

4. Tanggung jawab yang tinggi dalam menyukseskan suatu kegiatan

5. Keberhasilan ditentukan oleh prestasi sumber data manusia dalam perusahaan

6. Mengamati berbagai alternative keputusan yang diambil dapat dilaksanakan dengan baik dan tidak menyesali kegagalan masa lampau.

Dengan demikian dorongan untuk usaha adalah sebagai energi positif dari motivasi berwirausaha yang dapat membangkitkan motif berwirausaha bagi peserta didik. Menurut Yuyun Wirasasmita dalam (Suryana, 2013), sebagai dasar atau dorongan individu untuk membuka usaha adalah sebagai berikut:

1. Alasan finansial, adalah mendapatkan penghasilan, menjadi sukses, kaya, mapan, memperoleh bonus, sebagai bentuk kemapanan dalam perekonomian.

2. Alasan sosial, yaitu mendapatkan status sosial, untuk mendapatkan pengakuan dari orang lain, untuk menjadi kebangaan orang tua dihadapan masyarakat luas.

3. Alasan pelayanan, yaitu menciptakan lapangan pekerjaan bagi orang lain, memberikan pengetahuan bagi khalayak umum, menjaga stabilitas perekonomian bangsa, meraih impian dan cita-cita untuk generasi muda, keluarga, dan masyarakat, untuk mendapatkan kesetiaan suami/istri, untuk membahagiakan orang tua.

4. Alasan pemenuhan diri, supaya bisa mandiri, memperoleh sesuatu yang diinginkan. Supaya tidak selalu bergantung dengan orang lain, menjadi diri yang lebih produktif yg selalu melakukan sesuatu menggunakan potensi diri sendiri.

Bertitik tolak dari uraian di atas maka peneliti tertarik untuk mengadakan penelitian dengan judul "Pengaruh Pendidikan Kewirausahaan dan Motivasi Berwirausaha Terhadap Sikap Mental Kewirausahaan Peserta Didik SMA Negeri 21 Bekasi."

Rumusan masalah dalam penelitian ini adalah: (1) Apakah terdapat pengaruh Pendidikan Kewirausahaan dan Motivasi Berwirausaha secara simultan Terhadap Sikap Mental Kewirausahaan Peserta Didik SMA Negeri 21 Bekasi? (2) Apakah terdapat pengaruh Pendidikan Kewirausahaan secara partial terhadap Sikap Mental Kewirausahaan Peserta Didik SMA Negeri 21 Bekasi? (3) Apakah terdapat pengaruh Motivasi Berwirausaha secara partial terhadap Sikap Mental Kewirausahaan Peserta Didik SMA Negeri 21 Bekasi?

Tujuan dalam penelitian ini adalah: (1) Ingin memperoleh jawaban secara empirik pengaruh pendidikan kewirausahaan dan motivasi berwirausaha terhadap sikap mental berwirausaha peserta didik SMA Negeri 21 Bekasi. (2) Ingin memperoleh jawaban secara empirik pengaruh pendidikan kewirausahaan terhadap sikap mental berwirausaha pesera didik SMA Negeri 21 Bekasi. (3) Ingin memperoleh jawaban secara empirik pengaruh motivasi berwirausaha terhadap sikap mental berwirausaha peserta didik SMA Negeri 21 Bekasi.

\section{METHODS}

Metode penelitian yang digunakan adalah metode survei dengan pendekatan regresi linear berganda. Pengaruh antara variabel bebas dan tergantung. Penelitian ini dapat digambarkan dalam bentuk model analisis regresi linear berganda, seperti pada gambar 1. 


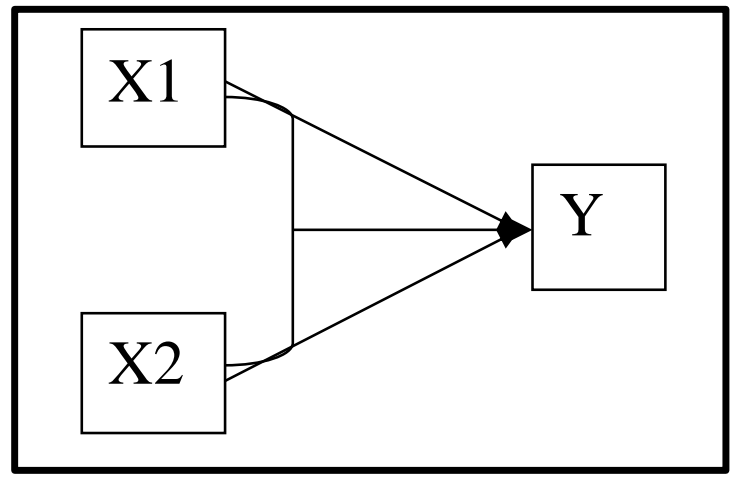

Gambar 1.

Model Regresi Linear Berganda Sumber: peneliti (2021)

Keterangan:

X1 : Pendidikan Kewirausahaan

X2 : Motivasi Berwirausaha

Y : Sikap Mental Berwirausaha

Populasi dalam penelitian ini adalah seluruh peserta didik kelas XII Sekolah Menengah Atas Negeri 21 Bekasi yang berjumlah 110 peserta didik.

Tabel 2.

Jumlah Populasi

\begin{tabular}{ccc}
\hline No & Kelas & Jumlah \\
\hline 1 & IPS 1 & 40 \\
2 & IPS 2 & 40 \\
3 & IPA 1 & 30 \\
\hline Jumlah & & $\mathbf{1 1 0}$ \\
\hline Sumber: SMA N 21 Bekasi &
\end{tabular}

Sumber: SMA N 21 Bekasi

Sampel penelitian ini sebanyak 110 peserta didik SMA N 21 yang ditentukan dengan menggunakan teknik sampel jenuh. (Sugiyono, 2015) sampel jenuh adalah teknik penentuan sampel bila semua anggota populasi digunakan sebagai sampel. Namun pada kenyataanya sampel yang digunakan dalam penelitian adalah 104 peserta didik, 6 peserta didik dianulir, karena ada beberapa pernyataan yang tidak terjawab.

Berikut ini adalah ringkasan hasil ujicoba instrument penelitian:

Tabel 3.

Ringkasan Hasil Uji Coba Instrumen

\begin{tabular}{ccccccc}
\hline No & Variabel & $\begin{array}{c}\text { Jenis } \\
\text { Instrumen }\end{array}$ & $\begin{array}{c}\text { Jumlah } \\
\text { Sebelum Uji }\end{array}$ & $\begin{array}{c}\text { Jumlah } \\
\text { Setelah Uji }\end{array}$ & Reliabilitas & Validitas \\
\hline 1 & $\begin{array}{l}\text { Pendidikan } \\
\text { kewirausahaan }\end{array}$ & Angket & 15 & 15 & 0,915 & $\begin{array}{c}\text { Rata-rata } \\
0,617\end{array}$ \\
2 & $\begin{array}{l}\text { Motivasi } \\
\text { Berwirausaha }\end{array}$ & Angket & 15 & 15 & 0,864 & $\begin{array}{c}\text { Rata-rata } \\
0,623\end{array}$ \\
3 & $\begin{array}{l}\text { Sikap Mental } \\
\text { Berwirausaha }\end{array}$ & Angket & 15 & 15 & 0,796 & $\begin{array}{c}\text { Rata-rata } \\
0,656\end{array}$ \\
\hline
\end{tabular}

Sumber: Data diolah peneliti (2021) 


\section{RESULTS \& DISCUSSION}

\section{Results}

Tabel 4.

Ringkasan Analisis Regresi Linear Ganda

\begin{tabular}{|c|c|c|c|c|c|c|c|}
\hline & $\mathbf{R}$ & KD & Sig. $f$ & f hitung & Sig. $t$ & t hitung & $\begin{array}{c}\text { Persamaan } \\
\text { Regresi }\end{array}$ \\
\hline \multirow{2}{*}{$\begin{array}{l}\mathrm{X} 1 \\
\mathrm{X} 2\end{array}$} & \multirow[b]{2}{*}{0,756} & \multirow[b]{2}{*}{$57,1 \%$} & \multirow[b]{2}{*}{0,000} & \multirow[b]{2}{*}{67,325} & 0,000 & 4,331 & $\mathrm{Y}=15,668+$ \\
\hline & & & & & 0,000 & 7,736 & $\begin{array}{c}0,271 X 1+0,545 \\
X 2\end{array}$ \\
\hline
\end{tabular}

Berdasarkan tabel 4 diketahui nilai korelasi sebesar 0,756 hal ini menunjukan bahwa nilai hubungan antara pendidikan kewirausahaan dan motivasi berwirausaha dengan sikap mental berwirausaha kuat sifatnya. Dari tabel 4 juga terlihat nilai Koefisien Determinasi pendidikan kewirausahaan dan motivasi berwirausaha dengan sikap mental berwirausaha sebesar $57,1 \%$, artinya kontribusi variabel pendidikan kewirausahaan dan motivasi berwirausaha memberikan sumbangsih kepada sikap mental berwirausaha sebesar $57,1 \%$ sedangkan sisanya yaitu sebesar $42,9 \%$ nilai sikap mental berwirausaha disumbang oleh variabel lain yang tidak diteliti.

Untuk persamaan regresi dietahui $\mathrm{Y}=15,668+0,271 \mathrm{X} 1+0,545 \mathrm{X} 2$ dari persamaan ini diartikan jika ada peningkatan 1 point pendidikan kewirausahaan dan motivasi berwirausaha maka juga akan terjadi peningkatan sikap mental berwirausaha peserta didik. Sedangkan untuk nilai uji signifikansi secara simultan diketahui nilai sig. (F) 0,000 hal ini menunjukkan bahwa nilai $0,000<0,05$ atau $F$ hitung $(67,325)>F$ tabel $(3,07)$ yang artinya terdapat pengaruh pendidikan kewirausahaan dan motivasi berwirausaha secara simultan terhadap sikap mental berwirausaha peserta didik. Sedangkan untuk uji lanjut variabel X1 secara partial diketahui nilai sig. (t) 0,000 hal ini menunjukkan bahwa nilai $0,000<0,05$ atau thitung $(4,331)>\mathrm{t}$ tabel $(1,960)$ yang artinya terdapat pengaruh pendidikan kewirausahaan secara partial terhadap sikap mental berwirausaha peserta didik. Sedangkan untuk uji lanjut variabel X2 secara partial diketahui nilai sig. (t) 0,000 hal ini menunjukkan bahwa nilai $0,000<0,05$ atau thitung $(7,736)>t$ tabel $(1,960)$ yang artinya terdapat pengaruh motivasi berwirausaha secara partial terhadap sikap mental berwirausaha peserta didik.

Hasil analisis menunjukkan adanya: (1) pengaruh positif dan signifikan variabel pendidikan kewirausahaan (X1) dan motivasi berwirausaha (X2) secara simultan terhadap sikap mental berwirausaha peserta didik (Y), (2) pengaruh positif dan signifikan variabel pendidikan kewirausahaan (X1) secara partial terhadap sikap mental berwirausaha peserta didik (Y), dan (3) pengaruh positif dan signifikan variabel motivasi berwirausaha (X2) secara partial terhadap sikap mental berwirausaha peserta didik.

\section{Discussion}

Hasil penelitian ini mendukung penelitian sebelumnya yang dilakukan oleh (Retno Budi Lestari dan Trisnadi Wijaya, 2012) hasil penelitian menyatakan bahwa Pendidikan kewirausahaan berpengaruh terhadap minat berwirausaha. Pendidikan kewirausahaan merupakan proses pembelajaran dalam merubah karakter dan konsep berpikir mahasiswa dalam memilih karier sebagai pencipta lapangan kerja bagi yang lain. Diharapkan bagi mahasiswa yang telah mengambil studi kewirausahaan memiliki nilai-nilai karakter dalam berwirausaha sehingga dapat menumbuhkan minat dan cinta dengan dunia usaha. 
Besarnya motif untuk berwirausaha akan melahirkan generasi muda yang akan terjun menjadi wirausahawan yang mempunyai tujuan yang jelas dimasa yang mendatang, daya cipta dan pembaharuan yang besar dalam segi kehidupan. Para wirausahawan yang memiliki karakter wirausaha bisa mengandalan diri sendiri, kreatif, dan menjadi pembaharu dalam melahirkan peluang bisnis baru dan melahirkan sesuatu yang berbeda. Masalah pengangguran terdidik akan dapat teratasi karena keluaran (output) dari hasil pendidikan kewirausahaan adalah calon-calon entrepreneur muda berbakat yang tidak lagi menjadi pencari kerja (job seeker) tetapi telah menjadi pencipta lapangan pekerjaan (job maker).

Penelitian ini sejalan juga dengan penelitian yang dilakukan (Wisnu Septian Ginanjar Prihantoro dan Syamsu Hadi, 2016) Inovatif, realistis, kreatif, komunikatif dan mandiri merupakan nilai-nilai yang harus ditanamkan pada mata pelajaran pendidikan kewirausahaan menurut Kemendiknas dalam (Mulyani, 2012). Seperti yang kita ketahui bahwa pendidikan kewirausahaan bisa membentuk karakter dan sikap seorang wirausaha. Menurut (Mulyani, 2012) "pendidikan kewirausahaan akan memotivasi peserta didik untuk memahami serta mampu menciptakan peluang baru dalam bisnis atau berwirausaha" hasil penelitian ini membuktikan pendapat beliau dengan analisis regresi untuk variabel pendidikan kewirausahaan sebesar 0,374. Dapat disimpulkan dari penelitian ini bahwa pendidikan kewirausahaan tidak hanya memberikan landasan teoritis mengenai konsep kewirausahaan namun juga membentuk sikap, perilaku dan pola pikir seorang wirausaha. motivasi berwirausaha yaitu alasan keuangan, alasan sosial, alasan pelayanan dan alasan pemenuhan diri berpengaruh secara positif sebesar 0,371 pada sikap mental kewirausahaan. Artinya keempat indikator variabel motivasi berwirausaha yang diungkapkan Yuyun Wirasasmita dalam (Suryana, 2013) di atas sesuai dengan hasil penelitian ini. Dari hasil analisis deskriptif variabel motivasi berwirausaha dalam kategori sangat tinggi dengan $100 \%$. Ini merupakan hasil luar biasa dimana $100 \%$ siswa jurusan pemasaran memiliki motivasi untuk berwirausaha yang sangat tinggi.

Hasil penelitian ini sejalan dengan penelitian yang dilakukan (Yanti et al., 2014) yaitu lingkungan keluarga berpengaruh terhadap sikap mental kewirausahaan. Indikator pada variabel lingkungan keluarga diambil dari teori Slameto dan hasil penelitian ini sesuai dengan teori beliau. Hasil analisis deskriptif presentase variabel lingkungan keluarga siswa masuk dalam kategori sangat baik sebesar $87,23 \%$ dan baik sebesar $12,77 \%$. Selanjutnya tiap indikator yaitu kondisi ekonomi keluarga dengan kategori sangat baik sebesar 44,68 dan baik 55,32 berarti siswa dalam kondisi ekonomi keluarga yang baik. Kemudian indikator cara orang tua mendidik, suasana rumah dan relasi antar anggota keluarga rata-rata siswa masuk dalam kategori sangat baik, namun pada indikator suasana rumah ada satu siswa yang masuk kategori kurang baik. Sikap mental kewirausahaan juga dapat ditingkatkan karena ada dorongan dari lingkungan keluarga. Kondisi ekonomi keluarga, cara mendidik orang tua, dll memiliki pengaruh kuat untuk menjadikan siswa SMK seorang yang memiliki mental wirausaha, dengan demikian SMK tidak hanya menciptakan siswa yang siap kerja namun juga menciptakan wirausahawirausaha baru. Sikap mental kewirausahaan adalah modal tak tampak yang mendasar dan harus dimiliki oleh wirausaha. Sikap mental kewirausahaan dapat dipengaruhi oleh beberapa faktor seperti pendidikan, pelatihan dan lingkungan sosial.

Hasil penelitian ini sejalan dengan teori yang dinyatakan oleh (Kurnianti, 2015) yang menyatakan bahwa faktor yang mempengaruhi minat berwirausaha terdiri dari dua aspek yaitu aspek intrinsik (pendapatan, harga diri, dan perasaaan senang) dan aspek ekstrinsik (lingkungan keluarga, lingkungan masyarakat dan pendidikan). Hasil penelitian ini juga mendukung teorinya (Alma, 2014), menyatakan bahwa latar belakang timbulnya minat berwiraushaa adalah pendidikan, lingkungan keluarga, nilainilai personal, usia, dan 
riwayat pekerjaan. Selain itu juga menyatakan bahwa keahlian dan keterampilan wirausaha banyak didapatkan dari pendidikan kewirausahaan.

Sejalan dengan (Maulida et al., 2016) yang menyatakan mahasiswa yang memiliki sikap mental wirausaha sangat rendah dan sangat tinggi jumlahnya paling sedikit. Mahasiswa yang memiliki sikap mental wirausaha tinggi memiliki jumlah paling banyak. Secara umum sikap mental wirausaha dalam bidang otomotif di kalangan mahasiswa prodi otomotif DPTM FPTK UPI Bandung ada pada kategori tinggi. Kesimpulan penelitian ini yaitu ada kecenderungan mahasiswa yang memiliki sikap mental wirausaha yang tinggi dapat berpotensi menjadi seorang wirausahawan.

Senada dengan (Ningsih, 2017) dengan hasil penelitian: (1) Pendidikan kewirausahaan adalah suatu proses atau kegiatan yang dilakukan dalam rangka menginternalisasi mental kewirausahaan, mentransmisi pengetahuan dan keterampilan kewirausahaan kepada peserta didik melalui Lembaga pendidikan formal (sekolah dan perguruan tinggi) maupun lembaga non formal (lembaga pelatihan) dalam upaya memanfaatkan peluang bisnis. (2) Motivasi wirausaha adalah daya penggerak yang menjadikan seseorang untuk melakukan usaha baru yang bersifat jangka panjang. Daya penggerak tersebut dapat berasal dari dalam diri berupa niat maupun dari luar diri berupa saran dan masukan. (3) Pendidikan kewirausahaan memiliki peranan dalam meningkatkan minat wirausaha mahasiswa. Sehingga perlu dikembangkan lebih baik lagi program atau kegiatan pendidikan kewirausahaan baik melalui pendidikan formal maupun non formal. Sejalan yang dilakukan oleh (Ngundiati \& Fitrayati, 2020) Berdasarkan hasil analisis data yang telah dilakukan, diperoleh informasi bahwa pendidikan kewirausahaan dan motivasi berwirausaha berpengaruh terhadap minat berwirausaha baik secara parsial maupun simultan. Besarnya kontribusi pengaruh pendidikan kewirausahaan dan motivasi berwirausaha terhadap minat berwirausaha sebesar $63,8 \%$, sisanya sebesar $36,2 \%$ dipengaruhi oleh variabel diluar penelitian.

\section{CONCLUSION}

1. Terdapat pengaruh pendidikan kewirausahaan dan motivasi berwirausaha secara simultan terhadap sikap mental berwirausaha peserta didik. Hal ini menandakan bahwa pendidikan kewirausahaan yang ada di sekolah dan dengan pemberian motivasi berwirausaha pada saat proses belajar dan pembelajaran dapat mempengaruhi sikap mental peserta didik dalam berwirausaha.

2. Terdapat pengaruh pendidikan kewirausahaan secara partial terhadap sikap mental berwirausaha peserta didik. Hal ini menandakan bahwa pendidikan kewirausahaan yang diberikan sekolah terbukti dapat meningkatkan sikap mental berwirausaha.

3. Terdapat pengaruh motivasi berwirausaha secara partial terhadap sikap mental berwirausaha peserta didik. hal ini menandakan bahwa motivasi berwirausaha yang diberikan guru pada saat proses belajar dan pembelajaran tebukti dapat meningkatkan sikap mental.

\section{REFERENCES}

Alma, B. (2014). Kewirausahaan. Alfabeta.

Kurnianti, E. D. (2015). Kewirausahaan Industri. Depublish.

Maulida, A. N., Kusumah, I. H., \& Permana, T. (2016). Karakteristik Sikap Mental Wirausaha Mahasiswa Dalam Bidang Otomotif. Journal of Mechanical Engineering Education, 3(1), 9. https://doi.org/10.17509/jmee.v3i1.3187 
Mulyani, E. (2012). Jurnal ekonomi \&amp; pendidikan: wadah kreativitas dan olah pikir ilmiah. Jurnal Ekonomi \& Pendidikan, 8(1), 1-18. https://journal.uny.ac.id/index.php/jep/article/view/705

Ngundiati, N., \& Fitrayati, D. (2020). Minat Berwirausaha ditinjau dari Pengaruh Pendidikan Kewirausahaan dan Motivasi Berwirausaha. Jurnal Pendidikan Ekonomi Undiksha, 12(2), 185-191.

Ningsih, R. (2017). Peranan Pendidikan Kewirausahaan Dalam Meningkatkan Motivasi Berwirausaha Bagi Mahasiswa. ProsidingLPPM Univ.Indraprasta PGRI, 2(3), 60.

Retno Budi Lestari dan Trisnadi Wijaya. (2012). Pengaruh Pendidikan Kewirausahaan Terhadap Minat Berwirausaha Mahasiswa. 1(2), 112-119.

Saiman, L. (2014). Kewirausahaan. Teori, Praktik, dan Kasus-kasus. Salemba Humanika.

Slameto. (2010). Belajar Dan Faktor-Faktor Yang Mempengaruhinya. Rineka Cipta.

Sugihartono dkk. (2013). Psikologi Pendidikan. UNY Press.

Sugiyono. (2015). Metode Penelitian Kuantitatif, Kualitatif, dan R\&D. CV Alfabeta.

Sumarsono, S. (2010). Kewirausahaan. Graha Ilmu.

Sunarso. (2010). Sikap Mental Wirausahawan dalam Menghadapi Perkembangan Zaman. Jurnal Ekonomi Dan Kewirausahaan, 10(2), 182-189.

Suryana. (2013). Kewirausahaan Pedoman Praktis, Kiat dan Proses Menuju Sukses. Salemba Empat.

Wisnu Septian Ginanjar Prihantoro dan Syamsu Hadi. (2016). Pengaruh Pendidikan Kewirausahaan, Motivasi Berwirausaha dan Lingkungan Keluarga Terhadap Sikap Mental Kewirausahaan. Economic Education Analysis Journal, 5(2), 705-717.

Yanti, P., Nuridja, I. M., \& Dunia, I. K. (2014). Pengaruh lingkungan keluargaTerhadap Berwirausaha Siswa Kelas XI Smk Negeri 1 Singaraja. Economic Education Analysis Journal, 4(1), 1-11.

Zimmerer, T. W. dan N. M. S. (2008). Kewirausahaan dan Manajemen Usaha Kecil. Salemba Empat. 